\title{
Pemberdayaan Raudlatul Athfal (RA) melalui Peningkatan Kualitas SDM Guru di Daerah Nelayan Kecamatan Tugu Kota Semarang
}

\author{
Muslam, Fatkuroji, Agus Khunaifi \\ Universitas Islam Negeri Walisongo Semarang \\ Email :muslam_alam@yahoo.co.id
}

\begin{abstract}
Community service activities is carried out by using pendekataan empowerment. The essence of this approach seeks to stimulate the independence process of the community (self sustaining process) of yourself. As a result of such devotion is the First, RA teachers achieved the standard HR professionals who are able to plan and carry out learning in accordance with Permindikbud clause of 146 and 137. Second; Participants devotion has two kinds of things, namely; 1) $80 \%$ of the training participants can understand the curriculum 13, to recognize the characteristics of learners, master models and learning strategies RA 2) $85 \%$ of participants proficient in motion and song, adept at making APE in learning and being able to make RPPH in RA. Third; Teachers increasingly skilled make APE and assign tasks meaningful to students, teachers are increasingly skilled in managing the class, and implement learning strategies.
\end{abstract}

Abstrak: Kegiatan pengabdian masyarakat ini dilakukan dengan menggunakan pendekataan pemberdayaan. Inti pendekatan ini berupaya merangsang proses pemandirian masyarakat (self sustaining process) dari diri sendiri. Adapun hasil dari pengabdian diantaranya adalah Pertama; Tercapainya standar SDM guru RA profesional yang mampu merencanakan dan melaksanakan pembelajaran sesuai dengan ketentuan permendikbud pasal 146 dan 137. Kedua; peserta pengabdian memiliki dua macam hal yaitu; 1) $80 \%$ Peserta pelatihan dapat memahami kurikulum 13, mengenali karakteristik peserta didik, menguasai model \& strategi pembelajaran RA 2) $85 \%$ peserta pelatihan mahir dalam gerak dan lagu, mahir membuat APE dalam pembelajaran serta mampu membuat RPPH di RA. Ketiga; Guru semakin trampil membuat APE dan memberikan tugas yang bermakna pada siswa, Guru semakin trampil dalam mengelola kelas, \& menerapkan strategi pembelajaran.

Kata Kunci: Pemberdayan, Kualitas SDM Guru RA dan Masyarakat Pantai 


\section{PENDAHULUAN}

Realitas saat ini menunjukkan bahwa di masyarakat kita terjadi peningkatan jumlah lembaga-lembaga penyelenggara pendidikan di jenjang PAUD. Menurut data balitbang tahun (2007) menunjukkan jumlah lembaga RA/BA di seluruh Indonesia cukup tinggi, yaitu berjumlah 18.886 lembaga, dengan kapasitas daya tampung sebanyak 808.828 anak. Menurut telaah strategis penyusunan Renstra 2010-2014, dalam empat tahun terakhir, perkembangan RA/BA menunjukkan angka yang cukup tinggi yaitu setiap tahun mengalami pertumbuhan sebanyak 7,10 \%. Angka ini menunjukkan tingginya partisipasi masyarakat untuk ikut mengembangkan Pendidikan Anak Usia Dini (PAUD) di Indonesia.

Namun demikian realitas saat ini menunjukkan bahwa tidak semua penyelenggara PAUD sudah memenuhi standar yang ditentukan. Menurut survei balitbang bahwa penyelenggaraan PAUD masih banyak yang belum memenuhi standar. Dengan kata lain tingginya partisipasi masyarakat serta cepatnya perkembangan lembaga RA/BA, ternyata belum diikuti dengan kualitas pembelajaran (mutu) yang standard. Menurut analisis Balitbang terdapat persoalan utama terkait dengan penyelanggaran PAUD yakni persoalan mutu / kualitas. Ditengarai ada dua titik lemah penyelenggaraan RA/BA, yaitu: Pertama, jumlah dan kualifikasi guru RA. Dari sisi jumlah dan kualifikasi, perbandingan antara jumlah peserta didik (808.828 anak) dengan jumlah guru PAUD yang berkualitas sangat tidak sebanding. Kedua, belum adanya instrumen standar baku, baik yang menyangkut standar materi, sarana prasarana, model pembelajaran, evaluasi, maupun instrumen lainnya, menyebabkan tidak sedikit RA yang membuat kurikulum sesuai dengan kehendak dan kecenderungan masing-masing lembaganya, sehingga mutu antara satu RA dengan RA lainnya bervariasi.

Secara khusus persoalan pengelolaan PAUD terjadi di lembaga-lembaga di daerah pesisiran. Persoalan-persoalan tersebut terkait dengan empat persoalan pokok yang dihadapi wilayah pesisir di Indonesia secara umum, yakni: (1) tingginya tingkat kemiskinan masyarakat pesisir. Tercatat, pada tahun 2010 kemiskinan di desa-desa pesisir mencapai angka 7 juta jiwa yang terdapat 10.639 desa pesisir; (2) tingginya kerusakan sumberdaya pesisir; (3) rendahnya kemandirian organisasi sosial desa dan lunturnya nilainilai budaya lokal; dan (4) rendahnya infrastruktur desa dan kesehatan lingkungan pemukiman. Keempat persoalan pokok ini juga memberikan andil terhadap tingginya kerentanan terhadap bencana alam dan perubahan iklim yang cukup tinggi pada desadesa pesisir.

Berdasarkan dengan persoalan-persoalan di atas maka kami bermaksud ikut berpartisipasi dalam rangka mengurai problem tersebut dengan melaksanakan program pengabdian masyarakat. Secara khusus bentuk pengabdian kami adalah dengan program pemberdayaan Raudlatul Athfal melalui peningkatan kualitas SDM para guru. Adapun 
objek pengabdian difokuskan pada lembaga RA di daerah pesisir atau nelayan. Sedangkan tujuan pengabdian adalah memberdayakan Lembaga RA agar menjadi sebuah lembaga PAUD yang berkualitas untuk kemajuan bangsa.

Secara khusus subjek dampingan yang dipilih adalah guru-guru RA di daerah nelayan Kec. Tugu Kota Semarang. Terdapat beberapa alasan mendasar terkait dengan pemilihan objek dampingan, diantaranya adalah rendahnya kualitas SDM guru dalam melaksanakan proses pembelajaran yang diberikan pada peserta didik (pembelajaran bersifat klasikal), dan rendahnya prestasi siswa baik akademik maupun non akademik, lembaga kurang sensitive terhadap tuntutan masyarakat, tidak mempunyai program unggulan yang kompetitif, masyarakat kurang mengenal prestasi lembaga RA, maka persoalan tersebut harus diatasi, salah satunya dengan melakukan pendanpingan melalui Participatory Action Research dalam bentuk Pemberdayaan RA melalui peningkatan kualitas SDM guru RA di daerah nelayan Kec. Tugu Kota Semarang.

Berkaitan dengan pemberian layanan kepada konsumen pendidikan, maka lembaga harus mengutamakan dengan memberikan pelayanan yang berkualitas. Konsep kualitas layanan pada dasarnya memberikan persepsi secara konkrit mengenai kualitas suatu layanan. Konsep kualitas layanan ini merupakan suatu revolusi secara menyeluruh, permanen dalam mengubah cara pandang manusia dalam menjalankan atau mengupayakan usaha-usahanya yang berkaitan dengan proses dinamis, berlangsung, terus menerus di dalam memenuhi harapan, keinginan dan kebutuhan. Hal ini sesuai dengan teori "Quality" yang dikemukakan oleh Marcel (2003:192) bahwa keberhasilan suatu tindakan jasa ditentukan oleh kualitas. Kualitas merupakan apresiasi tertinggi dari tindakan pelayanan.

Tabel 1.

Permasalahan dan solusi yang ditawarkan

\begin{tabular}{clll}
\hline No & \multicolumn{1}{c}{ Keadaan } & $\begin{array}{l}\text { Permasalahan } \\
\text { yang Timbul }\end{array}$ & Pemecahan Masalah \\
\hline 1. & $\begin{array}{l}\text { SDM RA (Guru dan } \\
\text { tenaga kependidikan) } \\
\text { tidak sesuai dengan } \\
\text { standar kompetensi }\end{array}$ & $\begin{array}{l}\text { SDM } \\
\text { melaksanakan } \\
\text { pendidikan/pe } \\
\text { mbelajaran asal } \\
\text { jalan }\end{array}$ & $\begin{array}{l}\text { Pelatihan/workshop } \\
\text { peningkatan kompetansi } \\
\text { guru dan tenaga } \\
\text { kependidikan }\end{array}$ \\
\hline 2. & $\begin{array}{l}\text { RA dipandang sebelah } \\
\text { mata oleh masyarakat, } \\
\text { tidak menarik, pengelola- } \\
\text { an asal asalan }\end{array}$ & $\begin{array}{l}\text { Animo rendah, } \\
\text { tidak laku } \\
\text { sehingga murid } \\
\text { jumlahnya } \\
\text { sedikit }\end{array}$ & $\begin{array}{l}\text { Pelatihan/workshop } \\
\text { penguatan pemasaran } \\
\text { layanan jasa pendidikan }\end{array}$ \\
\hline 3. & Mutu pendidikan rendah & $\bullet$ Pembelajaran & $\bullet$ Pelatihan Pembelajaran \\
\hline
\end{tabular}




\begin{tabular}{|c|c|c|}
\hline & $\begin{array}{l}\text { tidak } \\
\text { bermutu/tidak } \\
\text { menarik dan } \\
\text { konvensional } \\
\text { - Perangkat } \\
\text { pembelajaran } \\
\text { tidak ada } \\
\text { - Sarana } \\
\text { pembelajaran } \\
\text { tidak memadai } \\
\text { - Hasil tidak } \\
\text { bermutu }\end{array}$ & $\begin{array}{l}\text { guru dengan } \\
\text { BCCT/SELING/PAIK } \\
\text { EM untuk RA } \\
\text { - Workshop pembuatan } \\
\text { perangkat pembelajaran } \\
\text { - Pelatihan pembuatan } \\
\text { APE } \\
\text { - Pelatihan Manajemen } \\
\text { mutu dan peningkatan } \\
\text { budaya mutu }\end{array}$ \\
\hline $\begin{array}{l}\text { 4. Kelembagaan rendah } \\
\text { (Pengurus Yayasan dan } \\
\text { kepala RA tidak bermutu) }\end{array}$ & $\begin{array}{l}\text { - Peranserta } \\
\text { masyarakat } \\
\text { tidak ada } \\
\text { - Seolah-olah } \\
\text { lembaga milik } \\
\text { satu orang }\end{array}$ & Pelatihan MBS/MBM \\
\hline
\end{tabular}

Melihat kondisi dampingan saat ini belum maksimal target yang dicapai sebagaimana pada tabel 2, maka perlu didampingi, diarahkan, dibimbing dan diberi berbagai kompetensi yang berkaitan dengan peningkatan kualitas SDM guru RA, sehingga melalui program Pengabdian inilah akan kami wujudkan mutu pendidikan RA daerah nelayan Kecamatan Tugu Kota Semarang.

Pada prinsipnya seluruh program dan kegiatan pemberdayaan RA melalui peningkatan kualitas SDM guru Dalam Meningkatkan Mutu Pendidikan RA daerah nelayan Kec. Tugu Kota Semarang bertujuan pada peningkatan mutu dan relevansi serta mengembangkan kualitas sumber daya guru, sehingga memiliki kemampuan profesional untuk mengambil peranan dan tanggung jawab dalam mencerdaskan kehidupan bangsa.

Tabel 2.

Kondisi Subjek Dampingan

\begin{tabular}{cccc}
\hline No & Tugas Guru & \multicolumn{2}{c}{ Usaha Pemberdayaan } \\
\hline A. & Proses Pembelajaran & $\begin{array}{c}\text { Kopetensi } \\
\text { Sekarang }\end{array}$ & $\begin{array}{c}\text { Harapan } \\
\text { Setelah } \\
\text { Pemberdayaan }\end{array}$ \\
\hline 1 & $\begin{array}{c}\text { Menyusun program pembelajaran } \\
\text { tematik dan Kurikulum 2013 }\end{array}$ & $20 \%$ & $90 \%$ \\
\hline 2 & Menyajikan program pembelajaran & $20 \%$ & $95 \%$ \\
\hline 3 & Mengevaluasi proses dan hasil & $25 \%$ & $95 \%$ \\
\hline
\end{tabular}




\begin{tabular}{|c|c|c|c|}
\hline & pembelajaran & & \\
\hline 4 & $\begin{array}{l}\text { Manajemen kelas (tempat duduk } \\
\text { klasikal, model pembelajaran) }\end{array}$ & $20 \%$ & $95 \%$ \\
\hline 5 & $\begin{array}{l}\text { pelaksanaan kegiatan belajar } \\
\text { mengajar tepat waktu }\end{array}$ & $20 \%$ & $96 \%$ \\
\hline 6 & $\begin{array}{l}\text { pembelajaran model } \\
\text { BCCT/SELING/PAIKEM RA. }\end{array}$ & $20 \%$ & $90 \%$ \\
\hline B. & Produk Pembelajaran & & \\
\hline 1 & $\begin{array}{l}\text { kualitas produk yang dijaminkan } \\
\text { pada lulusan sekolah }\end{array}$ & $20 \%$ & $90 \%$ \\
\hline 2 & $\begin{array}{l}\text { standart mutu tiap komponen } \\
\text { sistem yang ditetapkan sekolah, }\end{array}$ & $20 \%$ & $90 \%$ \\
\hline 3 & $\begin{array}{l}\text { setiap orang di sekolah jelas } \\
\text { kontribusinya terhadap mutu yang } \\
\text { dijaminkan }\end{array}$ & $20 \%$ & $90 \%$ \\
\hline 4 & $\begin{array}{l}\text { Program unggulan sekolah yang } \\
\text { marketibel }\end{array}$ & $0 \%$ & $90 \%$ \\
\hline C. & Implementasi MBS & & \\
\hline 1 & RKS, RKT, RKAS/MBS & $20 \%$ & $95 \%$ \\
\hline 2 & $\begin{array}{l}\text { Peran serta masyarakat dan } \\
\text { transparansi \& akuntabilitas } \\
\text { lembaga ke public }\end{array}$ & $0 \%$ & $90 \%$ \\
\hline
\end{tabular}

Atas dasar uraian tersebut, inisiatif dan harapan program ini meliputi:

1. Para guru semakin meningkat pengetahuan dalam memberikan pelayanan proses pendidikan yang ditinjau dari proses pembelajaran. Tarjetnya 85\% guru RA daerah nelayan Kecamatan Tugu Kota Semarang proses pembelajaran menggunakan model BCCT/SELING/PAIKEM dan mengurangi model klasik.

2. Para guru semakin meningkat pengetahuan dan terampil dalam memberikan pelayanan proses pendidikan yang ditinjau dari variabel product (jaminan mutu produk pendidikan). Tarjetnya 75\% setiap program sekolah yang berkaitan dengan kompetensi siswa akan dijaminkan pada siswa atau orang tua.

3. Para guru semakin meningkat pengetahuan dan terampil dalam memberikan pelayanan proses pendidikan yang ditinjau people (staf pendidik yang professional). Tarjet $80 \%$ guru RA daerah nelayan Kec. Tugu Kota Semarang mempunyai ketrampilan tehnik mengunakan media, dan konsep dalam kegiatan belajar mengajar.

4. Para guru semakin terampil dalam memberikan pelayanan informasi yang edukatif pada masyarakat dengan harmonis. Tarjet 90\% guru-guru RA daerah nelayan Kec. Tugu Kota Semarang mampu menyampaikan informasi sekolah pada masyarakat 
melalui berbagai media cetak dan elektronik (spanduk, pamlet, brosur, radio dan lainnya.

Tabel 3.

Target Luaran Kegiatan Dampingan/Pengabdian

\begin{tabular}{|c|c|c|c|c|}
\hline Keadaan & Permasalahan & Pemecahan & Tolok Ukur & Alat Pencapaian \\
\hline $\begin{array}{l}\text { SDM guru RA } \\
\text { tidak sesuai } \\
\text { dengan standar } \\
\text { kompetensi }\end{array}$ & $\begin{array}{l}\text { SDM guru RA } \\
\text { melaksanakan } \\
\text { pendidikan/pembel } \\
\text { ajaran asal jalan }\end{array}$ & $\begin{array}{l}\text { Pelatihan/worksh } \\
\text { oppeningkatan } \\
\text { kompetansi guru } \\
\text { dan tenaga } \\
\text { kependidikan }\end{array}$ & $\begin{array}{l}\text { Tersedia } \\
\text { materi } \\
\text { Pelatihan } \\
\text { peningkatan } \\
\text { kompetensi } \\
\text { guru dan } \\
\text { tenaga } \\
\text { kependidikan }\end{array}$ & $\begin{array}{l}\text { Meningkatnya guru } \\
\text { dan ternaga } \\
\text { kependidikan }\end{array}$ \\
\hline $\begin{array}{l}\text { RA dipandang } \\
\text { sebelah mata } \\
\text { oleh } \\
\text { masyarakat, } \\
\text { tidak menarik, } \\
\text { pengelolaan } \\
\text { asal asalan }\end{array}$ & $\begin{array}{l}\text { Animo rendah, tidak } \\
\text { laku sehingga murid } \\
\text { jumlahnya sedikit }\end{array}$ & $\begin{array}{l}\text { Pelatihan/worksh } \\
\text { op penguatan } \\
\text { pemasaran } \\
\text { layanan jasa } \\
\text { pendidikan }\end{array}$ & $\begin{array}{l}\text { Tersedia } \\
\text { materi/pandu } \\
\text { an Pelatihan } \\
\text { pemasaran } \\
\text { layanan jasa } \\
\text { pendidikan }\end{array}$ & $\begin{array}{l}\text { Kemampuan } \\
\text { memasarkan } \\
\text { pendidikan } \\
\text { Animo masyarakat } \\
\text { meningkat. }\end{array}$ \\
\hline $\begin{array}{l}\text { Mutu } \\
\text { pendidikan } \\
\text { rendah }\end{array}$ & $\begin{array}{l}\text { Pembelajaran tidak } \\
\text { bermutu/tidak } \\
\text { menarik dan } \\
\text { konvensional } \\
\text { Perangkat } \\
\text { pembelajaran tidak } \\
\text { ada } \\
\text { Sarana } \\
\text { pembelajaran tidak } \\
\text { memadai } \\
\text { Hasil tidak bermutu }\end{array}$ & $\begin{array}{l}\text { Pelatihan } \\
\text { Pembelajaran } \\
\text { guru dengan } \\
\text { BCCT/SELIN } \\
\text { G/PAIKEM } \\
\text { untuk RA } \\
\text { Workshop } \\
\text { pembuatan } \\
\text { perangkat } \\
\text { pembelajaran } \\
\text { Pelatihan } \\
\text { pembuatan } \\
\text { APE } \\
\text { Pelatihan } \\
\text { Manajemen } \\
\text { mutu dan } \\
\text { peningkatan } \\
\text { budaya mutu } \\
\end{array}$ & $\begin{array}{l}\text { Tersedia } \\
\text { materi } \\
\text { pelatihan } \\
\text { pembelajaran, } \\
\text { perangkat } \\
\text { pembelajaran }\end{array}$ & $\begin{array}{l}\text { Meningkatkan } \\
\text { keterampilan } \\
\text { pembelajaran }\end{array}$ \\
\hline $\begin{array}{l}\text { Kelembagaan } \\
\text { rendah } \\
\text { (Pengurus } \\
\text { Yayasan dan } \\
\text { kepala RA } \\
\text { tidak bermutu) }\end{array}$ & $\begin{array}{l}\text { Peranserta } \\
\text { masyarakat tidak ada } \\
\text { Seolah-olah lembaga } \\
\text { milik satu orang }\end{array}$ & $\begin{array}{l}\text { Pelatihan } \\
\text { MBS/MBM }\end{array}$ & $\begin{array}{l}\text { Tersediannya } \\
\text { penduan } \\
\text { teknik MBM }\end{array}$ & $\begin{array}{l}\text { Pengelolaan } \\
\text { lembaga akuntabel, } \\
\text { PSM meningkat }\end{array}$ \\
\hline
\end{tabular}

\section{STRATEGI PENGABDIAN}

Strategi yang digunakan dalam pemberdayaan ini adalah Andragogi yang memiliki ciri transformative learning dan participatory training, di mana peserta orang dewasa yang 
telah memiliki pengetahuan, pengalaman, nilai-nilai (values), dan lingkungannya sendiri untuk dioptimalkan bersama para fasilitator.

Tabel 4.

Pola dan Metode implementasi Pengabdian

\begin{tabular}{|c|c|}
\hline Implementasi & Tahapan pelaksanaan \\
\hline $\begin{array}{l}\text { Pelatihan/workshop peningkatan } \\
\text { kompetansi guru dan tenaga } \\
\text { kependidikan }\end{array}$ & $\begin{array}{l}\text { - Diskusi tim dengan kepala RA, Guru } \\
\text { RA dan Tenaga kependidikan tentang } \\
\text { materi-materi pelatihan yang akan } \\
\text { disajikan dan yang dibutuhkan } \\
\text { - Kesepakatan tim dan kepala RA, } \\
\text { Guru RA dan Tenaga kependidikan } \\
\text { dalam menentukan waktu dan tempat } \\
\text { pelaksanaan pelatihan } \\
\text { - Penyusunan jadwal pelatihan yang } \\
\text { dibutuhkan } \\
\text { - Pelaksanaan pelatihan intensif }\end{array}$ \\
\hline $\begin{array}{l}\text { Pelatihan/workshop penguatan } \\
\text { pemasaran layanan jasa pendidikan }\end{array}$ & $\begin{array}{l}\text { - Diskusi tim dengan Pengurus, Kepala } \\
\text { dan Guru RA tentang materi-materi } \\
\text { pelatihan yang akan disajikan dan } \\
\text { yang dibutuhkan } \\
\text { - Kesepakatan tim dan Pengurus, } \\
\text { Kepala dan Guru RA dalam } \\
\text { menentukan waktu dan tempat } \\
\text { pelaksanaan pelatihan } \\
\text { - Penyusunan jadwal pelatihan yang } \\
\text { dibutuhkan } \\
\text { - Pelaksanaan pelatihan intensif }\end{array}$ \\
\hline $\begin{array}{l}\text { - Pelatihan Pembelajaran guru dengan } \\
\text { BCCT/SELING/PAIKEM untuk } \\
\text { RA } \\
\text { - Workshop pembuatan perangkat } \\
\text { pembelajaran } \\
\text { - Pelatihan pembuatan APE } \\
\text { - Pelatihan Manajemen mutu dan } \\
\text { peningkatan budaya mutu }\end{array}$ & $\begin{array}{l}\text { - Diskusi tim dengan Guru tentang } \\
\text { materi-materi pelatihan yang akan } \\
\text { disajikan dan yang dibutuhkan } \\
\text { - Kesepakatan tim dan Guru dalam } \\
\text { menentukan waktu dan tempat } \\
\text { pelaksanaan pelatihan } \\
\text { - Penyusunan jadwal pelatihan yang } \\
\text { dibutuhkan }\end{array}$ \\
\hline
\end{tabular}




\begin{tabular}{ll}
\hline & - Pelaksanaan pelatihan intensif \\
\hline Pelatihan MBS/MBM & Diskusi Tim dengan Pengurus \\
Yayasan dan Kepala RA tentang \\
MBS/MBM \\
- Gambaran MBM yang akan \\
diterapkan \\
- Diskusi tata cara pelaksanaan MBM \\
dan PSM \\
- Pendampingan penerapan MBM dan \\
PSM \\
\hline
\end{tabular}

Sedangkan Metode yang digunakan dalam pelatihan ini adalah: 1) Diskusi dengan subjek dampingan, 4) Role playing, 5) Action Plan, 6) Active learning, 7) Simulasi/ Peer Teaching. Adapun daur pemberdayan dapat dilihat pada gambar 1.

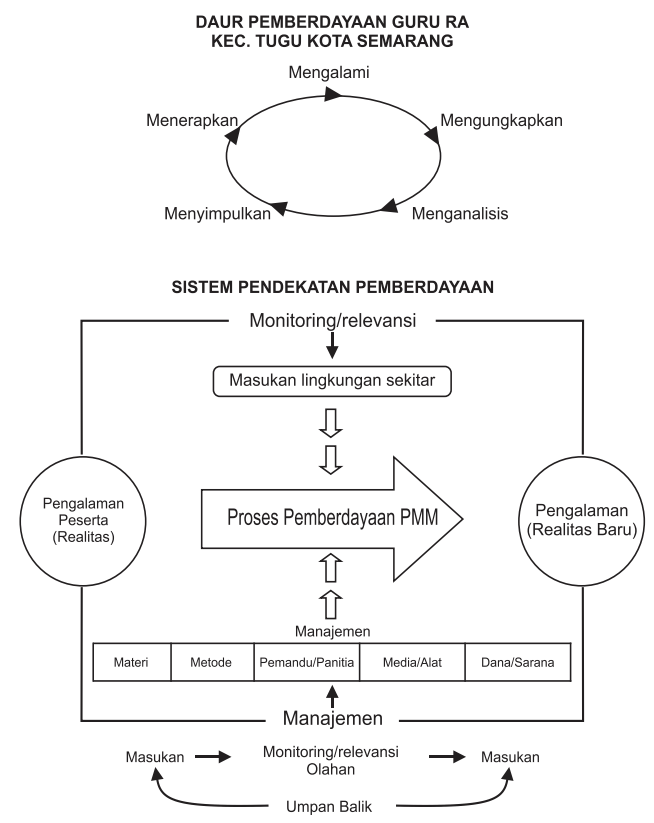

Gambar 1.

Alur pemberdayaan

Keberhasilan kegiatan Pemberdayaan RA melaui peningkatan kualitas SDM guru RA di Daerah Nelayan Kec. Tugu Kota Semarang sangat ditentukan oleh jejaring yang dibangun pada seluruh lini baik pada tingkat peran serta para guru, Kementrian Agama 
Kota, para pendamping dan tim ahli yang didatangkan untuk memberikan dampingan pada subjek dampingan. Pemahaman yang tepat akan visi, misi dan program kegiatan oleh berbagai pihak terkait sangat menentukan berhasil tidaknya program dampingan tersebut.

Untuk menjamin keberhasilan kegiatan pengabdian dan pendampingan melalui Participatory Action Research dengan kegiatan Pemberdayaan SDM Melalui Kualitas Layanan Jasa Pendidikan Dalam Meningkatkan Mutu Pendidikan RA daerah nelayan Kec. Tugu Kota Semarang diperlukan:

a. UIN Walisongo melalui (lewat Tim) Pengabdian harus mensosialisasikan budaya pelayanan prima pada lembaga pendidikan bagi guru pada Departemen Agama. Melalui sosialisasi ini diharapkan adanya pemahaman yang jelas terhadap program-program peningkatan Mutu pendidikan melalui pemberdayaan SDM pendidik, meliputi konsep pelayanan prima, tujuan pelayanan, manfaat pelayanan prima bagi RA dan konsumen, proses serta pelaksanaan monev sebagai upaya kontrol terhadap kualitas pelaksanaan kegiatan pemberdayaan di RA di daerah Nelayan Kec. Tugu Kota Semarang.

b. Bermitra dengan tim Pendidikan Profesi Guru/ PLPG FITK UIN Walisongo Semarang. Tim ini memberikan pelatihan proses pembelajaran yang berkualitas, metode pembelajaran, strategi pembelajaran efektif dan efesien.

c. Bermitra dengan Tim USAID Prioritas PAIKEM dan MBS. Selain berkolaborasi dengan TIM PPG, Tim USAID ini menekankan pada pelathan MBS/M. Jenis pelatihan diantaranya meningkatkan Peran Serta Masyarakat dalam Pendidikan (PSM), mentranparansikan program sekolah, pelathan penyusunan Rencana Kerja Sekolah (RKS), Rencana Kerja Tahunan (RKT), Rencana Kerja Anggaran Sekolah (RKAS).

d. Ma’arif Kota Semarang. Untuk menerima informasi tentang masalah yang berkaitan dengan keluhan sekolah.

\section{RESOURCESYANG SUDAH DIMILIKI}

a. Tim Pengabdian sekaligus TIM Pendidikan Profesi Guru/ PLPG mereka adalah asesor yang sudah mempunyai kemampuan dibidangnya dibuktikan sertifikat assessor PLPG/PPG serta memberikan pelatihan peserta PLPG dan PPG tiap tahun.

b. Tim dosen UIN FITK Jurusan PGRA, UNNES, Perguruan Tinggi Swasta dan LPMP, mereka adalah trainer propinsi dan Kabupaten yang selama ini sudah mendampingi di tingkat Kabupaten dan Propinsi di sekolah binaan UIN Walisongo dan UNNES. 


\section{KONSEP DAN ORIENTASI PENGABDIAN BERBASIS PEMBERDAYAAN}

Konsep pemberdayaan dalam kegiatan pengabdian masyarakat merupakan konsep yang sangat familier. Bahkan pemberdayaan (empowering) menjadi konsep yang sangat sering digunakan dalam event satu ini. Hal ini dikarenakan konsep pemberdayaan bersifat button up yakni muncul dari kesadaran masyarakat untuk ikut berpartisipasi dalam pembangunan. Dengan kata lain pemberdayaan dalam konteks ini merupakan upaya merangsang proses pemandirian masyarakat (self sustaining process). Artinya konsep pemberdayaan dimaksudkan untuk merubah kondisi masyarakat menjadi lebih baik berdasarkan kebutuhannya sendiri.

Pada umumnya kegiatan pemberdayaan difungsikan sebagai jembatan untuk merubah seseorang atau sekelompok orang dari kondisi semula yang kurang baik menjadi lebih baik. Di mana kelompok masyarakat dari strata sosial terendah sekali pun bisa saja terangkat dan muncul menjadi bagian dari lapisan masyarakat menengah dan atas. Namun demikian kegiatan pemberdayaan tidak dapat dilakukan sendiri oleh masyarakat yang bersangkutan. Melainkan kegiatan pemberdayaan membutuhkan pihak lain sebagai fasilitator. Artinya prinsip kegiatan pemberdayaan itu sendiri bukan saja diberi kesempatan akan tetapi mendapatkan bantuan atau terfasilitasi pihak lain yang memiliki komitmen untuk itu. Kelompok miskin di pedesaan misalnya, niscaya tidak akan mampu melakukan proses pemberdayaan sendiri tanpa bantuan atau fasilitasi pihak lain. Harus ada sekelompok orang atau suatu institusi yang bertindak sebagai pemicu keberdayaan (enabler) bagi mereka.

Secara spesifik karakteristik pemberdayaan adalah upaya melepaskan berbagai bentuk dominasi budaya, tekanan politik, eksploitasi ekonomi, yang menghalangi upaya masyarakat menentukan masalahnya sendiri serta upaya-upaya mengatasinya. Artinya karakteristik pemberdayaan berbeda dengan apa yang biasa disebut dengan pendekatan karitatif (memberi bantuan dengan dasar belas kasihan) dan pengembangan masyarakat (community development) yang biasanya berisi pembinaan, penyuluhan, bantuan teknis dan menejemen serta mendorong keswadayaan. Akan tetapi pemberdayaan adalah proses dari, oleh dan untuk masyarakat, di mana masyarakat didampingi/difasilitasi dalam mengambil keputusan dan berinisiatif sendiri agar mereka lebih mandiri dalam pengembangan dan peningkatan taraf hidupnya. Dengan demikian pemberdayaan menuntut hubungan simbosis mutualisme antara dua pihak yakni masyarakat bersangkutan dan fasilitator (Adi Sasono, 1998).

Dengan demikian maka dapat dipahami bahwa sasaran kegiatan pemberdayaan ini adalah masyarakat yang kurang beruntung; lemah, miskin atau tertinggal. Masyarakat tersebut kemudian difasilitasi untuk dapat mengembangkan potensinya agar dapat 
memiliki kemandiran di masa mendatang. Menurut Suharto (2005) setidaknya ada 4 sasaran pokok dari pemberdayaan itu sendiri yakni (a) mengembangkan kemampuan atau potensi yang dimilikinya untuk berkembang, (b) memenuhi kebutuhan dasarnya sehingga mereka memiliki kebebasan (freedom), terutama kebebasan dalam mengemukakan pendapat, (c) Menjangkau sumber-sumber produktif yang memungkinkan mereka dapat meningkatkan pendapatannya dan memperoleh barangbarang dan jasa-jasa yang mereka perlukan, dan (d) Berpartisipasi dalam proses pembangunan dan keputusan-keputusan yang mempengaruhi mereka, (lihat juga dalam Parsons, et al, 1994).

\section{PEMBERDAYAAN SDM GURU RAUDHATUL ATHFAL DAERAH PESISIRAN}

Sebagaimana penjelasan pada subbab di atas bahwa kegiatan pengabdian masyarakat kali ini dilaksanakan pada lembaga pendidikan Raudhatul Athfal di daerah psisiran. Kegiantan pengabdian dengan tema utama pemberdayaan Raudlatul Athfal Daerah Pesisiran ini didasarkan pada alasan alasan mendasar. Adapun permasalahan yang ada dalam subjek dampingan (guru RA daerah nelayan Kec. Tugu Kota Semarang) diantaranya; rendahnya kualitas SDM guru dalam melaksanakan proses pembelajaran yang diberikan pada peserta didik (pembelajaran bersifat klasikal), dan rendahnya prestasi siswa baik akademik maupun non akademik, lembaga kurang sensitive terhadap tuntutan masyarakat, tidak mempunyai program unggulan yang kompetitif, masyarakat kurang mengenal prestasi lembaga RA. Berdasarkan pemetaan problem tersebut maka kami melakukan pengabdian masyarakat dengan model pendanpingan melalui Participatory Action Research dalam bentuk Pemberdayaan RA melalui peningkatan kualitas SDM guru RA di daerah nelayan Kec. Tugu Kota Semarang.

Secara garis besar pemberdayaan dalam kegiatan ini digunakan dalam rangka mengembangkan dunia pendidikan di jenjang PAUD. Pemberdayaan di jenjang PAUD secara spesifik mengarah kepada terwujudnya organisasi layanan jasa pendidikan yang handal, professional, mandiri, bertangung jawab dan berkualitas dalam memberikan pelayanan kepada peserta didik. Adapun yang dimaksud layanan jasa pendidikan dalam hal ini meliputi process (bagaimana proses pembelajaran), product (adakah jaminan mutu produk pendidikan), price (besar kecilnya biaya pendidikan), place (lokasi sekolah yang strategis dan dan akses yang mudah kelokasi sekolah), promotion (informasi yang mampu memberikan edukasi pada masyarakat), people (staf pendidik dan kependidikan yang professional dan berprestasi), physical evidence (sarana dan prasarana yang memadai sesuai kebutuhan peserta didik). 
Ketujuh unsur tersebut dijadikan pedoman kami dalam melaksanakan pengabdian masyarakat di lapangan. Dengan kata lain lembaga-lembaga pendidikan yang kami pilih akan dirancang sedemikian rupa agar dapat menjadi lembaga yang mampu melayani konsumen pendidikan secara berkualitas. Adapun langkah kongkrit kami di awali dengan menjalin mitra TIM Pengabdian Masyarakat melalui Participatory Action Research (Jurusan PGRA FITK UIN Walisongo Semarang) dengan Tim PLPG/PPG. Jalinan mitra tersebut dibangun dalam rangka mewujudkan pemberdayaan SDM Guru dalam empat dimensi yang meliputi (1) process pembelajaran artinya meningkatkan pelatihan pembelajaran yang menyenangkan, (2) people (staf pendidik dan kependidikan yang professional dan berprestasi), (3) product, meningkatkan jaminan mutu produk pendidikan dalam setiap lulusan, dan (4) promotion (pelatihan untuk mengenal segmen pasar, pelatihan bauran pemasaran lembaga pendidikan (marketing mix).

Kegiatan pengabdian secara keseluruhan dilaksanakan dengan lima tahap yakni rapat koordinasi, SGD dan identifikasi kebutuhan pelatihan dan pelaksanaan pelatihan, pendampingan dan evaluasi. Adapun seluruh kegiatan pelatihan dijelaskan sebagai berikut. Pertama, Rapat Kordinasi. Rapat Kordinasi ini dilakukan pada Tanggal 9 Juli 2016, Hari Sabtu jam 10.30 WIB bertempat di RA HJ.SRI MUSIYARTI, dengan alamat JL.ANYER NO 4 KEL.BRINGIN bertemper di RA ini dikarenakan RA tersebut kepalanya selaku ketua IGRA Kota Semarang sehingga mepermudah dalam melakukan koordinasi dengan RA yang ada di kecamatan Tugu Kota semarang, koordinasi ini sebagai rapat kordinasi awal dengan kepala-kepala RA se-kecamatan Tugu Kota Semarang ditambah sebagaian RA yang ada di kecamatan Ngaliyan Kota Semarang. akan tetapi fokusnya pada RA-RA yang ada di daerah nelayan kecamatan Tugu Kota Semarang. Namun rapat koordinasi ini tidak hanya melibatkan seluruh kepala RA meleinkan melibatkan para pengurus IGRA baik IGRA Kota Semarang maupun IGRA Se-Kecamatan Tugu Kota Semarang sebagai penggerak dan pendorong kepada guruguru yang dibinanya dengan tujuan untuk memberikan masukan dan pengarahan.

Rapat kordinasi ini adalah sebagai langkah Mapping / Assessment yaitu dilakukan untuk mengadakan pemetaan dan penggalian informasi tentang kegiatan yang berkaitan dengan program peningkatan kualitas SDM guru RA dan kegiatan yang selama ini dilakukan oleh IGRA baik Kota Semarang maupun IGRA Kecamatan Tugu Kota Semarang yang terkait dengan hal tersebut. Sedangkan untuk melibatkan pengurus IGRA Kota Semarang maupun kecamatan Tugu Kota Semarang difungsikan sebagai Local Reseachers dan Lokal Organisers, dengan undangan dan pendekatan secara personal sehingga mereka menyempatkan untuk datang dan mengikuti rapat kordinasi tersebut.

Pada rapat kordinasi tersebut yang hadir diantaranya; Ketua IGRA Kota Semarang, Ketua IGRA Kecamatan Tugu, Kepala RA HJ.Sri Musiyarti, Kepala RA Nurul Ulum (dua RA tersebut Kecamatan Ngaliyan), sedangkan RA Kecamatan Tugu Kota 
Semarang yang hadir adalah; Kepala RA Miftahul Athfal, Kepala RA I'anatussibyan, Kepala RA Nurussibyan, Kepala RA Al Hidayah III, Kepala RA Masyitoh, Kepala RA Walisongo, dan Kepala RA Uswatun Hasanah. Penguru IGRA dan Kepala-Kepala RA tersebut diharapkan sebagai local Organisers dan lokal reseachers, dengan adanya para pengurus dan kepala-kepala RA ini diharapkan akan memiliki fungsi dalam pengambilan keputusan apapun yang terkait kelancaran kegiatan selanjutnya, memudahkan pelaksanaan kegiatan, dan sebagai mediator terhadap seluruh guru RA yang ada di kecamatan ngaliyan dan RA daerah nelayan di kecamatan Tugu Kota Semarang, terutama yang menjamin keberlasungan kegiatan pembelajaran sebagai wujud kualitas SDM guru RA pasca pendampingan.

Pada rapat kordinasi yang dilakukan adalah mapping / assessment terhadap hal-hal yang terkait dengan kebutuhan dan kegiatan yang harus dilakukan oleh IGRA Kota Semarang khususnya IGRA Kecamatan sebagai daerah nelayan yang menjadi fokus pengabdian, menetukan masalah yang timbul dari diadakanya kegiatan pengabdian tersebut, analisis terhadap masalah-masalah yang timbul, prioritas masalah dan perencanaan aksi yang diawali dengan Analisis Sumber Daya baik sumber daya manusia mapun Sumber Dananya. Dan terakhir adalah penentuan Aksi beberapa kegiatannya.

Adapun hasil dari rapat kordinasi ini telah diputuskan atau dihasilkan beberapa hal sebagai berikut:

a. Penentuan dan rekruetmen peserta, hal ini dilakukan terhadap seluruh guru RA di Kecamatan Tugu yang berjumlah tujuh (7) RA dan ditambah dua (2) RA yang ada dikecamatan ngaliyan yang dipandang perlu diikutsertakan dalam pendampingan yang berjumlah 55 orang, namun karena keterbatasan dana dan lain hal maka telah diambil keputusan peserta hanya diambil 20 orang guru dari keseluruhan guru (daftar peserta terlampir), sedangkan penetapan peserta dan rekruetmennya diserahkan sepenuhnya kapada Kepala RA dan pengurus IGRA Kota Semarang maupun Kecamatan Tugu Kota Semarang dengan pertimbangan keseriusan, minat dan keberlangsungan kegiatan tersebut, dan hal-hal sebagai berikut; Setiap RA Mendelegasikan Gurunya 2 orang; dengan mempertimbangkan persyaratan dari Tim Pengabdian yaitu: a) Pesrta wajib mengikuti dari awal sampai akhir dan bersedia didapingi, b) Peserta berijazah Strata satu (S1), c) Peserta bukan guru sertifikasi atau belum pernah ikut PLPG (artinya bagi guru sertifikasi yang dulu jalur portofolio diperbolahkan). Karena jumlah RA-nya 9 Maka biar genap 20 orang khusus untuk RA Nurul Ulum diminta mendelegasikan 4 orang guru sehingga genap 20 orang guru.

b. Waktu Kegiatan, waktu kegiatan disepakati; Kegiatan dilaksanakan pada Bulan Oktober 20016 setiap hari Sabtu dan Minggu hal ini mengambil waktu disela-sela liburan sekolah biar tidak menggagu proses pembelajaran, sedangkan kegiatan secara 
seremunial dilaksanakan pada Tanggal 28 s/d 29 Oktober 2016 dan selanjutnya diadakan pendampingan dan pemantauan dengan kesepakatan pihak guru sebagai peserta. dan direncanakan kegiatan pendampingan selama 2 bulan yaitu; Bulan November dan bulan Desember, yaitu kegiatan berakhir pada Tanggal 24 Desember 2016 yaitu hari Sabtu. Hal ini sesuai dengan berakhirnya program Pengabdian ini, dan untuk selanjutnya keberlangsungan kegiatan ini tanggung jawab diserahkan pada Kepala RA masing-masing dan pengurus IGRA baik Kota Semarang maupun IGRA Kecamatan Tugu Kota Semarang.

c. Tempat kegiatan pelatihan dipusatkan di Aula lantai 3 gedung Dekanat Fakultas Ilmu Tarbiyah dan Keguruan UIN Walisongo Semarang.

d. Materi Pelatihan dan pelatih/narasumber, setelah dilakukan penggalian informasi kebutuhan kegiatan ditetapkan materi pelatihan dan narasumber sebagai berikut:

1) Sessi 1; 1) Elemen Perubahan Kurikulum 2013 di PAUD/RA (involved regulasi terbaru) 2) SKL, KI dan KD di PAUD/RA 3) Perkembangan Anak PAUD/RA (Permendikbud 146 dan 137 tahun 2014) Narasumber: H. Mursid, M.Ag

2) Sessi 2 ; Model-model pembelajaran di PAUD/RA, Model pembelajaran berbasis SELING (sentra dan lingkaran) dengan Narasumber: H. Mursid, M.Ag dan Lilif Mu'analifah F. M.Pd.I.

3) Sesi 3; Gerak dan lagu (nyanyian sebagai metode pembelajaran yang efektif) dengan Narasumber: Mustakimah, M.Pd dan Nikmah Rahmawati, M.Si.Psi

4) Sesi 4; Konsep Media Pembelajaran di PAUD/RA, Praktek Pengembangan Media Pembelajaran di PAUD/RA (berbasis tema) Dengan Narasumber: Mustakimah, M.Pd.

5) Sesi 5; Konsep Pembelajaran Tematik, Dengan Narasumber: Nikmah Rahmawati, M.Si.Psi

6) Sesi 6; Konsep Penyusunan RKH dan Penilaian Autentik (Spritual, Sikap, Ketrampilan dan Kognitif), Praktik Penyusunan RKH Dengan Narasumber: Lilif Mu'analifah F., M.Pd.I

Pembiayaan kegiatan ini telah disepakati mengunakan dana pengabdian dan melibatkan swadaya dana dari Lembaga RA dan Pengurus IGRA terutama untuk menjaga keberlangsungan setelah program pendampingan berakhitr.

Kedua, SGD dan Identifikasi Kebutuhan Pelatihan. Setelah dilakukan rapat kordinasi telah teridentifikasi kebutuhan-kebutuhan dan juga permasalahanpermasalahan maka langkah selanjutnya tim bersama pengurus IGRA dan Kepala RA untuk melakukan pendalaman melalui SGD sehingga dapat diperoleh kesepakatan dan hasilnya sebagai prioritas masalah dan proiritas kebutuhan untuk dapat ditindaklanjuti sebagai prioritas masalah, perencanaan aksi, dan aksi. Adapun perencanaan secara menyeluruh dapat disusun jadwal pengabdian yang ditampilkan pada tabel 5 . 
Selanjutnya pelaksanaan kegiatan mengacu pada jadwal dan Time Schedule yang telah diputuskan bersama antara tim dan Kepala RA serta pengurus IGRA pada SGD.

Tabel 5.

Jadwal Pelaksanaan (Time Schedule) Kegiatan Pengabdian

\begin{tabular}{|c|c|c|c|c|c|c|c|}
\hline No. & Kegiatan & \multicolumn{6}{|c|}{ Bulan } \\
\hline & & 1 & 2 & 3 & 4 & 5 & 6 \\
\hline 1. & Pemetaan aktifitas Guru RA & $\mathrm{X}$ & & & & & \\
\hline 2. & Pelatihan SDM Pendidikan $\mathrm{R} A$ & & $\mathrm{X}$ & & & & \\
\hline 3. & Pelatihan MBS dan Menajemen & & & $\mathrm{X}$ & & & \\
\hline & Mutu Lembaga Pendidikan RA & & & & & & \\
\hline 4. & $\begin{array}{l}\text { Pelatihan Pemasaran Jasa Pendidikan } \\
\text { RA }\end{array}$ & & & & $\mathrm{X}$ & & \\
\hline 5. & $\begin{array}{l}\text { Pelatihan Pembelajaran Aktif, APE } \\
\text { dll. }\end{array}$ & & & $\mathrm{X}$ & & & \\
\hline 6. & Pembinaan/Pendampingan & & $\mathrm{X}$ & $\mathrm{X}$ & $\mathrm{X}$ & $\mathrm{X}$ & $\mathrm{X}$ \\
\hline 7. & Pembuatan laporan & & & & & & \\
\hline & Penyajian data & & & & $\mathrm{X}$ & $\mathrm{X}$ & \\
\hline & Analisis data & & & & & $\mathrm{X}$ & \\
\hline 8. & Diskusi laporan pengabdian & & & & & & $\mathrm{X}$ \\
\hline 9. & Perbaikan laporan & & & & & & $\mathrm{X}$ \\
\hline 10. & Penyampaian laporan pengabdian & & & & & & $\mathrm{X}$ \\
\hline
\end{tabular}

Ketiga, Kegiatan Pelatihan-pelatihan. Kegiatan pelatihan-pelatihan ini mengacu peda apa yang dihasilkan pada pemetaan kebutuhan dan permasalah yang muncul dan telah di olah pada SGD, sehingga kegiatan-kegiatan pelatihan yang dilakukan pada pengabdian ini dilakukan dengan berbagai pertimbangan baik dari pihak tim pengabdi maupun pihak RA dan IGRA terutama mengacu pada kesiapan dan kemungkinan waktu pada RA, IGRA dan masing-masing guru.

\section{PENDAMPINGAN, TINDAK LANJUT, DAN EVALUASI}

Dalam pendampingan ini dilakukan selama 2 bulan yaitu mulai bulan Oktober 2016 setelah pelatihan, yaitu bulan Nopember dan Desember 2016, pedampingan dilakukan sesuai kesepatan anatara Tim Pengabdian dengan guru-guru yang didampingi yatiu setiap satu minggu sekali, biar tidak membebani guru dengan mekanisme masingmasing guru yang mau di dampingi membuat perencanaan dan perangkat 
pembelajaranyang akan dilaksanakan pada pembelajaran kemudian dikunsultasikan pada tim pengebdian kemudian diberikan saran-saran perbaikan dan dilaksanakan dengan dipatau oleh tim dan setelah pembelajaran dilakukan diskusi bersama untuk mengatasi kekurangan-kekukarangan dan permasalahan yang timbul pada pembelajaran. Pemdampingan ini dilaksanakan selama 2 bulan, yaitu bulan November sampai dengan Desember 2016 dan kegiatan ini berakhir pada tanggal 24 Desember 2016.

Sebagai tindak lanjut dari kegiatan pengabdian ini di harapkan ada keberlanjutan (Sustainable) dari apa yang telah dimiliki dari pengabdian ini dan bahkan diharapkan dapat dikembangakan yang lebih maju lagi, untuk itu Kepala-kepala RA dan Pengurus IGRA bai Kota maupun kecamatan dan Pengurus Yayasan RA setempat melakukan pembinaan dan menjaga Sustainablelity/keberlanjutan dari kegiatan dan hasil dari pengabdian ini, dan tim pengabdian meskipun kegiatan pengabdian ini telah berakhir tetap menjalin komunikasi dan melakukan pemantaun sampai bener-benar dapat dilepas secara mandiri.

Kegiatan evaluasi dilakukan sebagai bentuk refleksi dalam semua kegiatan yang telah direncanakan dalam perencanaan aksi dan telah dilaksananakan pada aksi, adapaun kegiatan evaluasi ini dilakukan melalui dua tahap yaitu;

a. Evaluasi periodik, evaluasi ini ada beberapa jenis yang dapat dilakukan; 1) dilaksanakan pada setiap akhir latihan sebagai refleksi, hal ini dilakukan dengan maksud untuk menggali permasalahan-permasalah yang timbul selama latihan dan sekaligus mencari sulusi pemecahannya, 2) dilaksananak setiap akhir bulan hal ini dilakukan untuk melakukan evaluasi dan refleksi kegiatan selama satu bulan yang telah lalu baik kendala maupun analisis sumbner daya yang telah ada untuk mempertajam perencanaan aksi bulan berikutnya dan mengantisipasi permasalahan yang timbul dan pemecahan permasalahan pada bulan berikutnya.

b. Evaluasi Akhir Program, evalusi ini dilakukan pada akhir program, yaitu untuk menentukan hasil akhir yang telah dicapai dan selajutnmya untuk melakukan Rencana Tindak Lanjut (RTL) dan untuk menetukan langkah yang harus dilakukan setelah program pendampingan selesai.

\section{HASIL KEGIATAN}

Dari kegiatan pengabdian ini yang dihasikan adalah hal-hal berikut ini: pertama, Guru RA Daerah Nelayan Kecamatan Tugu Kota Semarang setelah diadakan pelatihan dan orientasi tentang:

a. Materi tentang Kurikulum PAUD/RA yang meliputi; 1)Elemen Perubahan Kurikulum 2013 di PAUD/RA (involved regulasi terbaru) 2) SKL, KI dan KD di PAUD/RA 3) Perkembangan Anak PAUD/RA (Permendikbud 146 dan 137 tahun 2014) sedikit banyak telah memiliki pemahaman tentang bagaimana cara 
memahami kurikulum, mendesain kurikulum PAUD/RA beserta perangkat pembelajaran yang menyertai dalam pembelajaran di PAUD/RA, sehingga kurikulum yang terapkan sesuai dengan karakter dan perkembangan ank Usia Dini/RA.

b. Sedangkan pelatihan selanjutnya adalah Pelatihan dan Praktik Model-model pembelajaran di PAUD/RA, Model pembelajaran berbasis SELING (sentra dan lingkaran) dengan, materi ini oleh peserta dipandang sangat penting dikarenakan bahwa sementara ini pembelajaran di RA rata-rata dilaksanakan secara konfensional/Tradional dikarenakan kurangnya pengetahuan dan ketrampilanm tentang model-model pembelajaran terutama sentra dan lingkaran (BCCT).

c. Materi pelatihan berikutnya adalah Pelatihan dan Praktik Gerak dan lagu (nyanyian sebagai metode pembelajaran yang efektif), ini menjadi prasarat bagi guru RA sehingga materi ini memang materi yang sifatnya praktis.

d. Materi Pelatihan yang tidak kalah pentingnya adalah materi tentang Konsep Media Pembelajaran di PAUD/RA dan Praktek Pengembangan Media Pembelajaran di PAUD/RA (berbasis tema), yang sering disebut dengan pengembangan Alat Permaianan Edukatif yang disingkat dengan APE, ini penting mengingat banyak keterbatasan RA tentang APE tersebut sehingga guru dituntut untuk kreatif bisan membuat dan mengembangakan sindiri APE yang dibutuhkan.

e. Materi Pelatihan berikutnya adalah materi tentang Konsep Pembelajaran Tematik, materi ini sesuai dengan Permendikbud 137 yang kalau tidak difahami dengan benar akan mengalami kesulitan.

f. Materi pelatihan yang terakhir adalah Konsep Penyusunan RPPH dan Penilaian Autentik (Spritual, Sikap, Ketrampilan dan Kognitif), serta Praktik Penyusunan RPPH materi ini sebagai simpul pelatihan dari keseluruhan materi pelatihan yang ada dalam bentuk perangkat pembelajaran yang harus disipakan oleh guru dan disampng itu pada pendampingan nanti yang dilahat adalam administrasi perangkat pembelajaran yang ada pada RPPH dan dilihat pakteknya pada Pembelajaran.

Kedua, Terbentuk kualitas SDM guru RA yang profesional pada masing-masing pribadi guru yang mampu merencanakan dan melaksanakan pembelajaran sesuai dengan ketentuan permendikbud 146 dan 137, dan sesuai dengan kompetensi sesuai dengan standar nasional guru PAUD/RA di daerah nelayan kecamatan Tugu Kota Semarang.

Ketiga, Keberlangsungan upaya peningkatan kualitas SDM guru RA melalui pendampingan-pendampingan secara swadaya perlu dilakukan baik oleh RA dari masingmasing maupun IGRA secara organisasi profesi sebagai sarana pemberdayaaan RA di daerah nelayan kecamatan Tugu secara khusus maupun secara umum RA di Kota 
Semarang. Dan Keempat, Perlu dikembangkan pelatihan-pelatihan skala kecil antar guru terutama yang belum mengikuti pelatihan oleh guru yang sudah selesai pelatihan dan pendampingan sebagai bentuk penularan pengetahuan dan ketrampilan.

\section{KESIMPULAN}

Kesimpulan utama dari Pemberdayaan Raudlatul Athfal (RA) Melalui Peningkatan Kualitas SDM Guru antara lain:

1. Terbentuk kualitas SDM guru RA yang profesional pada masing-masing pribadi guru yang mampu merencanakan dan melaksanakan pembelajaran sesuai dengan ketentuan Permendikbud 146 dan 137, dan sesuai dengan kompetensi sesuai dengan standar nasional guru PAUD/RA di daerah nelayan kecamatan Tugu Kota Semarang.

2. Keberlangsungan upaya peningkatan kualitas SDM guru RA melalui pendampingan-pendampingan ini secara swadaya perlu dilakukan baik oleh RA dari masing-masing maupun IGRA secara organisasi profesi sebagai sarana pemberdayaaan RA di daerah nelayan kecamatan Tugu secara khusus maupun secara umum RA di Kota Semarang.

3. Hasilnya peserta pengabdian dinyatakan telah memiliki dua macam hal yaitu; 1) 80\% Peserta pelatihan dapat memahami kurikulum 13, mengenali karakteristik peserta didik, menguasai model\& strategi pembelajaran RA 2) 85\% peserta pelatihan mahir dalam gerak dan lagu, mahir membuat APE dalam pembelajaran serta mampu membuat RPPH di RA

4. Hasil pendampingan secara keseluruhan: Guru semakin trampil membuat APE dan memberikan tugas yang bermakna pada siswa, Guru semakin trampil dalam mengelola kelas, \& menerapkan strategi pembelajaran, Sejumlah 20 guru dari 9 RA nampak peningkatan pengetahuan mereka secara signifikan tetang pelaksanaan Proses Pembelajaran, Penilaian Pembelajaran, Sejumlah 20 guru dari 9 RA terlihat kemajuan keterampilan guru dalam menyiapkan Perangkat Pembelajaran.[

\section{DAFTAR PUSTAKA}

Anonymous, 2001, Lampiran I Keputusan Menteri Pendidikan Nasional Nomor 053/U/2001, Kementerian Pendidikan Nasional Republik Indonesia.

Anonymous, 2004, Buku Pedoman Pembakuan Sekolah, Departemen Pendidikan Nasional. 
Anonymous, 2004, Keputusan Menteri Pendayagunaan Aparatur Negara Nomor KEP/75/M.PAN/7/2004, Kementerian Pendayagunaan Aparatur Negara.

Anonymous, 2007, Lampiran Peraturan Menteri Pendidikan Nasional Nomor 24 Tahun 2007, Standar Sarana dan Prasarana Untuk Sekolah, Kementerian Pendidikan Nasional Republik Indonesia.

Anonymous, 2008, Peraturan Pemerintah Nomor 74 Tahun 2008 Tentang Guru, Kementerian Pendidikan Nasional Republik Indonesia

Arikunto, S. 1998. Prosedur Penelitian Suatu Pendekatan Praktek. Jakarta: Rineka Cipta

Basuno, dkk. 2005. Kaji Tindak (Action Research) Pemberdayaan Masyarakat Pertanian di Wilayah Tertinggal. Laporan Penelitian. Pusat Penelitian dan Pengembangan Sosial Ekonomi Pertanian. IPB, Bogor.

Buku Pedoman Pelaksanaan Uji Kompetensi Guru, Kementerian Pendidikan dan Kebudayaan Direktorat Jenderal Guru dan Tenaga Kependidikan. 2015.

Buku Pedoman Pelaksanaan Penilaian Kinerja Guru, Kementerian Pendidikan dan Kebudayaan Direktorat Jenderal Guru dan Tenaga Kependidikan. 2015.

Craig, RL 1987; Trainning and Development Handbook, a Guide to Human Resourre Development; American Society for Training and Development (ASTD), McGraw Hill Book Company.

Castetter B. William, 1996, The Personal Function in Educational Administration, McMillian.

Ford, R.C. \& M.D. Fottler. 1995. Empowerment: a matter of degree. Academy of Management EXECUTIV E, August, 21-29.

Hadari Nawawi. 2000. Manajemen Strategic (Organisasi Non Profit Bidang Pemerintahan). Yogyakarta: Gadjah Mada University Press 2015.

Kemmis, S., dan McTaggert, R. 1990. The Action Research Planner. Geelong: Deakin University Press. 
Sukardi. 2003. Metodologi Penelitian Pendidikan (Kompetensi dan Praktiknya). Jakarta: Bumi Aksara.

Sarwono, Jonathan. 1995. Penuntun Penelitian Praktis, Bandung: Universitas Kristen Maranatha

Pedoman Penyusunan Modul Diklat Pengembangan Keprofesian Berkelanjutan bagi Guru dan Tenaga Kependidikan. Kementerian Pendidikan dan Kebudayaan, Direktorat Jenderal Guru dan Tenaga Kependidikan.

Undang-Undang Nomor 14 Tahun 2005 tentang Guru dan Dosen.

Veithzal Rivai. 2004. Manajemen Sumber Daya Manusia untuk Perusahaan, Jakarta: PT. Raja Grafindo Persada. 